\title{
Optimization of extraction procedure and determination by high performance liquid chromatography of flavonols and phenolic acids from Hypericum Perforatum L.
}

\author{
(INDEX: 62-73/2010 Copernican Letters ${ }^{\circledR}$ Vol 1) \\ Anna Filipiak-Szok, Marzanna Kurzawa, Edward Szłyk \\ Faculty of Chemistry, Nicolaus Copernicus University, 7 Gagarin str., \\ 87-100 Torun, Poland; \\ e-mail: $\underline{\text { ania_f@doktorant.umk.pl }}$
}

\begin{abstract}
Hypericum perforatum is a medicinal plant which has been known in traditional medicine as an antiinflammatory and healing agent. Nowadays the use of Hypericum extracts is concerned mainly with antidepressive applications. In the present work, HPLC $R P-C_{18}$ column chromatography with photodiode array detection was applied for the determination of the derivatives of cinnamic and benzoic acid (e.g., caffeic, chlorogenic, ferulic, sinapic, gallic acids) (Fig.1.) and flavonols - quercetine derivatives (quercetine, rhamnetine, quercitrin, mirycetine, keampferol and rutin) in Hypericum Perforatum. Phenolic compounds were extracted from the sample matrix with ethanol and ethanolwater mixture in different ratios solvent $(3: 7 ; 8: 2 ; v / v)$ at $30^{\circ} \mathrm{C}$ and $60^{\circ} \mathrm{C}$ in water-bath shaker and by ultrasonic extraction and then analyzed before and after acid and basic hydrolysis. The total amount of studied flavonols and phenolic acids were compared with the total flavonoids content (TFC) and with total polyphenols content (TPC). $U V$-Vis spectrometry was used to investigate methods for qualitative and quantitative determination of these compounds.
\end{abstract}

Keywords: Hupericum perforatum L., HPLC-PDA, flavonols, phenolic acids, TPC, TFC

\section{Introduction}

Hypericum perforatum L. is a herbaceous perennial plant widely distributed in Europe, Asia, and North Africa; it is also naturalized in North America [1]. It is well known as "St. John's wort" in Anglo-Saxon folk medicine and "Erba di S. Giovanni" in Italy. It is well known as a medicinal plant and its extracts are used as an anti-inflammatory, healing agent and an antidepressant medicine, which has been demonstrated in numerous clinical trials challenging the conventional antidepressant drugs [2]. The part of this activity is attributed also to the drug antimicrobial activity [3]. Hypericum extracts are marketed not only as herbal medicinal products but also in the form of dietary supplements [4]. In recent years, the consumption of $\mathrm{H}$. perforatum - derived products has increased dramatically and presently it is one of the most consumed medicinal plant over the world [5].

Hypericum perforatum contains a variety of constituents with documented biological activity including naphthodianthrones (hypericin, pseudohypericin, protohypericin and protopseudohypericin), phloroglucinols (hyperforin and adhyperforin), a broad range of flavonoids (quercetin, quercitrin, isoquercitrin, hyperoside, astilbin, miquelianin, I3 and II8-biapigenin), and phenolic acids (chlorogenic acid and 3-Ocoumaroylquinic acid), epigallocatechin, and other minor components. [3] The flavonoids comprising the aglycone quercetin and several glycosides, namely hyperoside(quercetin-3-galactopyranoside), rutin (quercetin-3-rhamnosylglucoside) and quercitrin (quercetin-3rhamonopyranoside). Flavonoids present in $H$. perforatum L. extracts have been shown to have antidepressive activities [6].

Determination of compounds in plant materials requires extraction from the sample matrix prior to injection into the HPLC system. Flavonoids are commonly extracted from herbal samples with pure 
methanol, ethanol or their combination with water [7-9], but in some cases ethyl acetate [4] or acetone [10] have been used. The optimum extraction conditions varied depending on the active compounds as well as on the kind of plant. Determination of individual flavonoid glycosides in plant materials is difficult, due to their large number. In many cases the knowledge of the total aglycone content for each flavonoid is required. Walle et al. [11] reported, that the dietary form of flavonoids, the flavonoid glycosides, may be hydrolyzed in the oral cavity by bacteria to deliver the biologically active aglycones at the surface of the epithelial cells. Hydrolysis of all glycosides to aglycones allows to obtain more accurate data on flavonol concentrations in food samples. This process is dependent on the concentration of $\mathrm{HCl}$, hydrolysis time and temperature and the composition of the extraction solvent [12]. Moreover, different extraction procedures are indicated in the various Pharmacopeias.

Isolation and purification of bioactive compounds in H. perforatum L. using HPLC and macroporous resin has been reported [13-15]. Generally, HPLC methods of $\mathrm{H}$. perforatum preparations are concerned with the determination of flavonoids content [16]. High-speed counter-current chromatography (HSCCC), being a support-free liquid-liquid partition method [17], eliminates irreversible adsorption of sample onto the solid support, and has been widely used in preparative separation of natural products [18-20]. CCC has also been used in isolating flavanoids from $H$. perforatum L. [22]. In many cases, preparative high-performance liquid chromatography (prep-HPLC) is a method needed to satisfy the purity specifications required on a routine basis, and it is also an important industrially applied separation process for the isolation and purification of pharmaceuticals and other valuable products [22]<smiles>[2H]c1cc(C(=O)O)cc(Br)c1P</smiles>

Benzoic acid<smiles>[R]c1cc(/C=C/C(=O)O)c(Br)c([R])c1[2H]</smiles>

Cinnamic acid
Benzoic acid :

Gallic acid $\quad\left(\mathrm{R}_{1}=\mathrm{R}_{2}=\mathrm{R}_{3}=\mathrm{OH}\right)$

Cinnamic acid:

Ferulic acid $\left(\mathrm{R}_{1}=\mathrm{R}_{2}=\mathrm{H} ; \mathrm{R}_{3}=\mathrm{OH} ; \mathrm{R}_{4}=\mathrm{OCH}_{3}\right)$; Caffeic acid $\left(\mathrm{R}_{1}=\mathrm{R}_{4}=\mathrm{H} ; \mathrm{R}_{2}=\mathrm{R}_{3}=\mathrm{OH}\right)$;

Sinapic acid $\left(\mathrm{R}_{1}=\mathrm{H} ; \mathrm{R}_{3}=\mathrm{OH} ; \mathrm{R}_{2}=\mathrm{R}_{4}=\mathrm{OCH}_{3}\right)$;

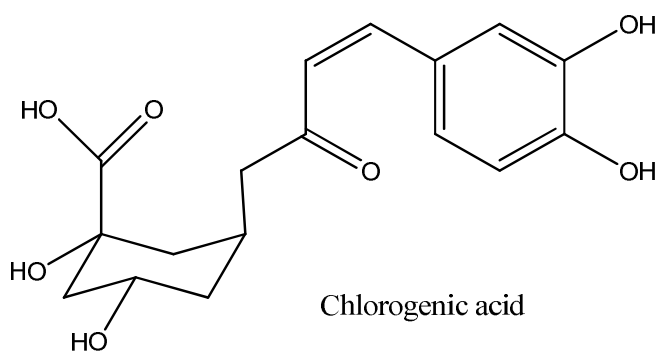

Fig. 1. Structural skeletons of main phenolic acids [23]<smiles>Cc1cc(-c2oc3c(C)c(C)cc(C)c3c(=O)c2C)cc(C)c1C</smiles>

Quercetin 3, 5, 7, 3', $4^{\prime}=\mathrm{OH}$

Mirycetin: 3, 5, 7, 3', 4', 5' $=\mathrm{OH}$

Kaempferol: 3, 5, 7, $4^{\prime}=\mathrm{OH}$ 
<smiles>O=c1c(OC2OC3C4CC2C(O)C(O4)C3O)c(-c2ccc(O)c(O)c2)oc2cc(O)cc(O)c12</smiles><smiles>CCCCCCCCCCCCCO</smiles><smiles>CCCCCCOc1c(O)cc(O)cc1OC1OC2C(c3c(-c4ccc(O)c(O)c4)oc4cc(O)cc(O)c4c3=O)OC1C(O)C2O</smiles>

Fig. 2. Structural skeletons of main flavonols [23]

The main aim of this work was to investigate the optimum conditions for efficient extraction of studied flavonols and benzoic and cinamic acid derivatives from $\mathrm{H}$. perforatum. For quercetin analysis as aglycone the effects of acid concentration and hydrolysis time on the extraction recovery were also investigated.

\section{Experimental}

\subsection{Chemicals and samples}

Every one of quercetin derivatives and also caffeic and chlorogenic acids were purchased from SIGMA ALDRICH (Germany), while ferulic, sinapic acids from FLUKA (USA). Gallic and benzoic acids were purchased from POCh (Gliwice, Poland).

The phenolic compounds were isolated from Hypericum Perforatum L. (purchased from the Pharmaceutical Company, Biofaktor, Gorzów Wielkopolski). The purity and structural identity of each isolated compound were chemically characterized by HPLC-PDA.

Methanol

CHROMASOLV®, isopropanol and tetrahydrofuran were from SIGMA Aldrich (Germany). Every one of solvents were HPLC grade. Methanol, ethanol, glacial acetic acid, hydrochloric acid (35-38\%) and sodium hydroxide were from Chempur (Piekary Śląskie, Poland). Folin-Ciocalteu's Phenol Reagent and disodium carbonate were purchased from POCh (Gliwice, Poland).

\subsection{Apparatus}

The HPLC system consisted of liguid chromatograph equipped with auto sampler SIL-20AC HT a photodiode multiwavelenght detector (SPD-M20A prominence diode array detector) made by SHIMADZU (Kyoto, Japan). The absorption was measured either as a full spectrum (200 $-800 \mathrm{~nm}$ ) and at $254 \mathrm{~nm}$ (for benzoic and gallic acids), $325 \mathrm{~nm}$ (for caffeic, chlorogenic, sinapic and ferulic acids) and $360 \mathrm{~nm}$ for quercetin derivatives. The chromatographic data were rocorded and processed by the LCsolution version 1.23 SP.

UV-VIS spectra were recorded on a Spectrophotometer UV Unikam HELIOS $a$, manufactured by Spectro-Lab (Warsaw, Poland). $1 \mathrm{~cm}$ quartz cuvette was using. 


\subsection{Chromatographic conditions}

The chromatographic data were rocorded and processed by the LCsolution version 1.23 SP. Analyses were carried out at on Discovery RP-C 18 column $(5 \mu \mathrm{m}$ particle size, $150 \times 4,6 \mathrm{~mm}$, SUPELCO). A column was maintained at $30^{\circ} \mathrm{C}$.

For phenolic acids mobile phase A was $2 \%$ acetic acid and phase B was methanol (HPLC grade). For studied flavonols, mobile phase A was mixture of waterisopropanol $(95: 5, \mathrm{v} / \mathrm{v})$ and phase B were water:isopropanol:THF (50:40:10, v/v). The analysis every one od studied polyphenols followed a nonlinear gradient program (Fig. 3 and Fig.4).

The flow-rate was kept constant at 1 $\mathrm{ml} / \mathrm{min}$. The injection volume was $10 \mu \mathrm{l}$ and $20 \mu \mathrm{l}$ for phenolic acids and flavonols, respectively. The detection was performed at the maximum UV-VIS absorptions of the ten compunds: at $254 \mathrm{~nm}$ (for benzoic and gallic acids) and $325 \mathrm{~nm}$ (for caffeic, chlorogenic, sinapic and ferulic acids) and $360 \mathrm{~nm}$ for every one of studied flavonols.

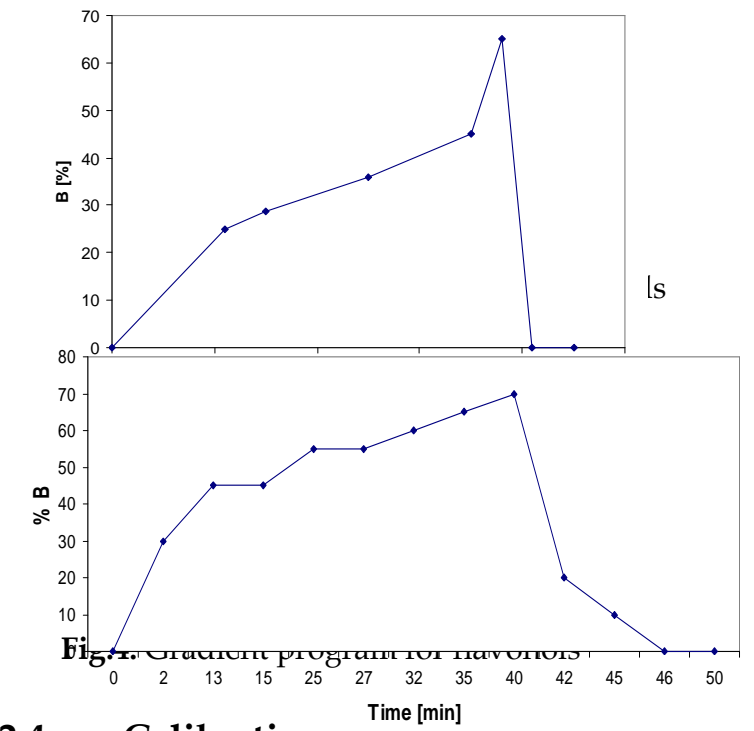

\subsection{Calibration curves}

Gallic, caffeic, chlorogenic, ferulic, sinapic, benzoic acids were dissolved in methanol/water mixture $(8: 2, \mathrm{v} / \mathrm{v})$, while flavonols were dissolved in $\mathrm{MeOH}$ (HPLC grade) and diluted to appropriate concentration ranges for the construction of calibration curves. The calibration curves were based on the analysis of 5 repetition standards at 12 concentration levels for phenolic acids (Table 1) and for quercetin derivatives (Table 2). These curves were constructed by plotting the area peak as a function of the concentration.

\subsection{Extraction procedure}

The extraction system consisted of ethanol $(\mathrm{EtOH})$ and ethanol-water in different ratios solvent $(3: 7 ; 8: 2 ; \mathrm{v} / \mathrm{v})$ for phenolic compounds. The total volume of cold extract was shared for 3 portions (at the same volume). One of these extract portions was filtered through a soft quantitative filter paper into a chromographic vial and volumetric flask.

Two portions of the extract were successively hydrolyzed by acidic and basic digestion. Samples were analyzed before and after acidic and basic hydrolysis.

If the extract was not clear, about $2 \mathrm{ml}$ of the extract was transferred to $5 \mathrm{ml}$ centrifuge tubes and centrifuged for $15 \mathrm{~min}$ at high speed centrifuge. The clear supernatant was transferred to an LC sample vial. Extractions were performed in duplicate. The detail procedures for HPLC quantitative analysis were described above.

\subsection{Quantification of polyphenols in Hypericum perforatum $L$.}

0.5 gram $(0.01 \mathrm{~g})$ of fine powder Hypericum perforatum L. were exctracted with ethanol and ethanol-water in different ratios $(3: 7 ; 8: 2 ; \mathrm{v} / \mathrm{v})$ solvents two times. Each extraction was performed using a water - bath shaker at $30^{\circ} \mathrm{C}$ and $60^{\circ} \mathrm{C}$ within 1 and 2 hour and also using ultrasonic extraction at the same temperature within 15 and $30 \mathrm{~min}$.

\subsection{Extraction followed by acid or/and basic hydrolysis}

Three portions of the extract were successively hydrolyzed by acidic and basic 
digestion. Samples were analyzed before and after acidic and basic hydrolysis. The solution was filtered through a soft quantitative filter paper or centrifuged before HPLC analysis.

Basic hydrolysis (was assigned II): Five milliliters of the extract was placed in a $100 \mathrm{ml}$ conical flask and $300 \mu \mathrm{l}$ of $3 \mathrm{M}$ $\mathrm{NaOH}$ was added. The extract was swirled at $30^{\circ} \mathrm{C}$ for $30 \mathrm{~min}$.

Acid hydrolysis (was assigned III): Five milliliters of extract was placed in a $100 \mathrm{ml}$ conical flask with $1 \mathrm{ml}$ of concentrated $\mathrm{HCl}$. The flasks were heated for $30 \mathrm{~min}$ at $30^{\circ} \mathrm{C}$ in a water-bath shaker.

\subsection{UV-VIS spectral studies}

\subsubsection{The total polyphenols content (TPC)}

The amount of total polyphenols in the extract was determined according to the Folin-Ciocalteau method. Caffeic acid and quercetin were employed as a calibration standard and results were expressed as caffeic acid and quercetin equivalents, respectively. The absorbance of the test solution was measured at $725 \mathrm{~nm}$ after $1 \mathrm{~h}$.

Reagents were dissolved in bidistilled water. For quantitative assays, the solution were prepared by appropriate dilution (1.0; $2.0 ; 4.0 ; 6.0 ; 8.0 ; 10.0 ; 12.0 ; 16.0 \mu \mathrm{g} / \mathrm{ml})$ of freshly prepared stock-solution $(20 \mu \mathrm{g} / \mathrm{ml})$. Before diluting, $0.20 \mathrm{ml}$ Follin-Ciocalteu's solution and $0.50 \mathrm{ml}$ of disodium carbonate solution $(0.07 \mathrm{~g} / \mathrm{ml})$ were added. The calibration curves were based on the analysis of 5 repetition standards at 8 concentration levels. These curves were constructed by plotting the absorbance as a function of the caffeic acid concentration.

Test soltution $-0.60 \mathrm{ml}$ Folin-Ciocalteu's Phenol Reagent and $0.50 \mathrm{ml}$ of disodium carbonate solution $(0.07 \mathrm{~g} / \mathrm{ml})$ were mixed in $10 \mathrm{ml}$ volumentric flask and diluted with distilled water. Test solution was kept without light for $1 \mathrm{~h}$. For sample assaying, $50 \mu \mathrm{l}$ of extract was introduced to $5 \mathrm{ml}$ volumetric flask.

\subsubsection{The total flavonoids content (TFC)}

The total flavonoids content (TFC) was determined using a colorimetric method described in Polish Farmacopoeia. Quercetin was employed as a calibration standard and results were expressed as quercetin equivalents. The absorbance of the test solution was measured at $428 \mathrm{~nm}$ after $30 \mathrm{~min}$. [24]

Quercetin was dissolved in ethanol. For quantitative assays, the solution were prepared by appropriate dilution (1.0; 3.0; $5.0 ; 7.0 ; 9.0 ; 10.0 ; 12.0 ; 14.0 \mu \mathrm{g} / \mathrm{ml})$ of freshly prepared stock-solution $(20 \mu \mathrm{g} / \mathrm{ml})$. Before diluting in mixture of acetic acid $(1,02 \mathrm{~kg} / \mathrm{l})$ and methanol $(1: 19, \mathrm{v} / \mathrm{v}), 1.20$ $\mathrm{ml}$ aluminium chloride $(20 \mathrm{~g} / \mathrm{l})$ solution was added. The calibration curves were based on the analysis of 5 repetition standards at 8 concentration levels. These curves were constructed by plotting the absorbance as a function of the quercetin concentration.

Test soltution $-1.20 \mathrm{ml}$ aluminium chloride $(20 \mathrm{~g} / \mathrm{l})$ were put in $10 \mathrm{ml}$ volumentric flask and diluted with mixture of acetic acid $(1,02 \mathrm{~kg} / \mathrm{l})$ and methanol $(1: 19, \mathrm{v} / \mathrm{v})$. Test solution was kept without light for $30 \mathrm{~min}$. For sample assaying, $50 \mu \mathrm{l}$ of extract was introduced to $10 \mathrm{ml}$ volumetric flask.

\section{Result and discussion}

Peaks on the chromatograms were identified by comparison of the retention times and UV spectra of the peaks in extractions with those of the reference standards. Peaks were also identified by addition of the individual reference standard to extracts. The purity of each peak was checked by PDA software. Typical chromatograms for Hypericum perforatum extract are presented at Fig. 5 . Because of complex biological samples, identification every peaks was impossible. Gallic and benzoic acids were detected at 
$254 \mathrm{~nm}$, while chlorogenic, caffeic, ferulic, sinapic acids at $325 \mathrm{~nm}$. Derivatives of quercetine (quercetine, rutin, quercitrin, rhamnetin, mirecetine, kaempferol and hyperoside) were detected at $360 \mathrm{~nm}$.

The regression coefficient of each calibration curve was higher than 0.99 . Calibration curves in HPLC-PDA method were constructed by plotting the area peak as a function of the concentration. The results are collected in Table 1 and Table 2. Detection limit (DL) was not lower than $0.28 \mathrm{mg} / 1$ and $0.35 \mathrm{mg} / 1$ (for hiperoside and gallic acid, respectively) and not higher than $1.82 \mathrm{mg} / \mathrm{l}$ and $7.55 \mathrm{mg} / 1$ (for quercitrin and chlorogenic acid, respectively) and range of quantification limit (QL) was 1.08 $24.04 \mathrm{mg} / 1$ (Table 1) and 0.85 - $5.51 \mathrm{mg} / 1$ (Table 2).

In spectrophometry method - TPC and TFC - calibration curves were constructed by plotting the absorbance as a function of the concentration of the caffeic acid and quercetine, respectively. The regression coefficient of each calibration curve was also higher than 0.99 (unpublished data). Detection limit (DL) for TFC and TPC was $0.31 \mu \mathrm{g} / \mathrm{ml}$ and $0.63 \mu \mathrm{g} / \mathrm{ml}$, respectively.

All the examined extracts were significantly active as antioxidant agents. The result of the total polyphenols amount (TPC) in the extracts determining by the Folin-Ciocalteau method are presented at Figure 6, including the impact of various extraction conditions, such as method (water+bath and ultrasonic extraction), time (15 and $30 \mathrm{~min}$, and also 1 and $2 \mathrm{~h}$ ), and temperature $\left(30^{\circ} \mathrm{C}\right.$ and $\left.60^{\circ} \mathrm{C}\right)$. The best results were obtained by ethanolic extraction. Obtained results demonstrate also, that not only solvents have influence for exctraction procces. The highest concentration of polyphenolic compunds were obtained by ultrasonic extraction at $60^{\circ} \mathrm{C}$ and $30 \mathrm{~min}$. In every cases ultrasonic extraction increase recovery and short preparation time.
At Figure 7 are presented corelation between total phenolic content (TPC) and total flavonoids content (TFC). The corelation is good (the regression coefficient $\left.\mathrm{R}^{2}=0.9758\right)$. In every cases, total concentration of polyphenols (TPC) was higher than total amount of flavonoids and flavonols determination by HPLC-PDA method (presented in Table 3). TFC was also higher than concentration of studied phenolic acids and studied flavonols determination by HLC-PDA method. In general flavonols (such as rutin, quercetin, quercitrin kaempferol and hyperoside) are among the major compounds in Hypericum perforatum herb. Hovewer studied flavonols and phenolic acids constitute only smart part of total polyphenols presented in H. perforatum $\mathrm{L}$.

At Figure 8. are presented impact of different extraction conditions (only ultrasonic extraction) and hydrolysis digestion for the total phenolic content (TPC) in Hypericum perforatum herb. Hydrolysis step has been included to minimize interferences in subsequent chromatography and to simplify chromatographic data. Acidic and alkaline hydrolysis, prior to extraction caused the increase the quantitative yield. The influence of hydrolyzed digestion is significantly. For determination polyphenols the highest concentration were obtained after acidic hydrolysis. Acidic hydrolysis was better for flavonols and phenolic acids, while alkaline hydrolysis was adequate for phenolic acids. Acidic hydrolysis has been used to measurement of aglycones and phenolic acids from flavonoid glicosides and phenolic acid esters.

Alkaline hydrolysis has been approached in the isolation of phenolic acids, due to they commonly form covalent bond with the sample matrix. Phenolic acids exist in a wide range of conjugated forms.

At Table 4 there were presented literature data for comparison of flavonols 
content [25-28]. The range of concentration of studied quercetine derivatives determination by HLC-PDA method before and after hydrolysis digestion were the same at demonstrated data. We could compare our data with others authors data and corroborate that discribing in this paper HPLC-PDA method is precision, selective and accuracy.

Table 1.

Linear calibration curves for six phenolic acids (standards)

\begin{tabular}{|c|c|c|c|c|c|c|}
\hline \multirow[t]{2}{*}{ Phenolic acid } & \multicolumn{2}{|c|}{$y=a x+b,{ }^{*}$ the linear model } & \multirow{2}{*}{$\begin{array}{l}\text { Regression } \\
\text { coefficient } r^{2}\end{array}$} & \multirow{2}{*}{$\begin{array}{c}\text { Range of } \\
\text { concentration [mg/l] }\end{array}$} & \multirow{2}{*}{$\begin{array}{c}\mathrm{DL} \\
{[\mathrm{mg} / \mathrm{l}]}\end{array}$} & \multirow{2}{*}{$\begin{array}{c}\mathrm{QL} \\
{[\mathrm{mg} / \mathrm{l}]}\end{array}$} \\
\hline & $a \pm S_{a}$ & $b \pm S_{b}$ & & & & \\
\hline gallic acid & $18480 \pm 188$ & $5412 \pm 1186$ & 0.9990 & $0.06-130$ & 0.35 & 1.08 \\
\hline chlorogenic acid & $28406 \pm 264$ & $136259 \pm 69405$ & 0.9992 & $0.05-600$ & 7.98 & 24.04 \\
\hline caffeic acid & $54327 \pm 430$ & $48342 \pm 48260$ & 0.9994 & $0.10-300$ & 7.55 & 22.87 \\
\hline ferulic acid & $52874 \pm 292$ & $11271 \pm 29473$ & 0.9997 & $0.50-200$ & 4.63 & 14.04 \\
\hline sinapic acid & $52692 \pm 815$ & $78950 \pm 27412$ & 0.9976 & $0.10-70$ & 3.30 & 10.00 \\
\hline benzoic acid & $5024 \pm 41.7$ & $18527 \pm 4387$ & 0.9994 & $0.50-200$ & 6.66 & 20.19 \\
\hline
\end{tabular}

${ }^{*} \mathrm{x}$ - concentration, $\mathrm{y}$ - peak area; $\mathrm{a}$ - slope; $\mathrm{b}$ - intercept, $\pm \mathrm{Sa}, \pm \mathrm{Sb}$ - standard deviation of slope and intercept; detection limit $\mathrm{DL}=\left(3.3 \mathrm{~S}_{\mathrm{x} / \mathrm{y}}\right) / \mathrm{a}$; quantification limit $\mathrm{QL}=\left(10 \mathrm{~S}_{\mathrm{x} / \mathrm{y}}\right) / \mathrm{a} ; \mathrm{S}_{\mathrm{x} / \mathrm{y}}-$ standard deviation of $\mathrm{y}$-residuals

Table 2.

Linear calibration curves for quercetin derivatives (standards)

\begin{tabular}{|c|c|c|c|c|c|c|}
\hline \multirow[t]{2}{*}{ Flavonols } & \multicolumn{2}{|c|}{$y=a x+b,{ }^{\star}$ the linear model } & \multirow{2}{*}{$\begin{array}{l}\text { Regression } \\
\text { coefficient } r^{2}\end{array}$} & \multirow{2}{*}{$\begin{array}{c}\text { Range of } \\
\text { concentration [mg/l] }\end{array}$} & \multirow{2}{*}{$\begin{array}{c}\mathrm{DL} \\
{[\mathrm{mg} / \mathrm{l}]}\end{array}$} & \multirow{2}{*}{$\begin{array}{c}\mathrm{QL} \\
{[\mathrm{mg} / \mathrm{l}]}\end{array}$} \\
\hline & $\mathbf{a} \pm \mathrm{S}_{\mathrm{a}}$ & $b \pm S_{b}$ & & & & \\
\hline quercetin & $30065 \pm 412$ & $5131,3 \pm 9739$ & 0.9987 & $2.24-44.80$ & 1.80 & 5.47 \\
\hline rutin & $22164 \pm 261$ & $5104,3 \pm 7324$ & 0.9990 & $4.16-52.00$ & 1.74 & 5.27 \\
\hline hiperoside & $16979 \pm 1529$ & $-33514 \pm 7802$ & 0.9994 & $0.40-10.00$ & 0.28 & 0.85 \\
\hline kaempferol & $37672 \pm 330$ & $-18017 \pm 2529$ & 0.9994 & $0.60-15.00$ & 0.41 & 1.24 \\
\hline rhamnetin & $24676 \pm 651$ & $-3452,8 \pm 3322$ & 0.9945 & $0.40-10.00$ & 0.82 & 2.49 \\
\hline quercitrin & $44009 \pm 734$ & $-80465 \pm 13117$ & 0.9978 & $1.40-35.00$ & 1.82 & 5.51 \\
\hline mirecetine & $21217 \pm 449$ & $-11759 \pm 2638$ & 0.9978 & $0.80-10.00$ & 0.58 & 1.75 \\
\hline
\end{tabular}

* $\mathrm{x}$ - concentration, $\mathrm{y}$ - peak area; a - slope; $\mathrm{b}$ - intercept, $\pm \mathrm{Sa}, \pm \mathrm{Sb}$ - standard deviation of slope and intercept; detection limit $\mathrm{DL}=\left(3.3 \mathrm{~S}_{\mathrm{x} / \mathrm{y}}\right) / \mathrm{a}$; quantification limit $\mathrm{QL}=\left(10 \mathrm{~S}_{\mathrm{x} / \mathrm{y}}\right) / \mathrm{a} ; \mathrm{S}_{\mathrm{x} / \mathrm{y}}-$ standard deviation of y-residuals 
Table 3.

Quercetine derivetives content of Hypericum perforatum L. extract determined by HPLC-PDA method (ultrasonic extraction)

Name of flavonols

\section{Quercetine derivetives content of Hypericum perfor
s.m \pm SD]}

$15 \mathrm{~min}$

$30^{\circ} \mathrm{C}$

Rutin

Hyperoside

Quercitrin

Mirecetine

Quercetine

Keampferol

Rhamnetine

TOTAL

\section{$60^{\circ} \mathrm{C}$}

$2.13 \pm 0.03$

$0.89 \pm 0.01$

$1.40 \pm 0.01$

$0.54 \pm 0.004$

$1.57 \pm 0.009$

$0.52 \pm 0.004$

$0.003 \pm 0.0001$

$7.05 \pm 0.04$ $30^{\circ} \mathrm{C}$

$2.73 \pm 0.03$

$1.00 \pm 0.02$

$2.52 \pm 0.01$

$0.69 \pm 0.002$

$2.71 \pm 0.02$

$0.7 \pm 0.0005$

nd

$10.37 \pm 0.03$
$30 \mathrm{~min}$

\section{$60^{\circ} \mathrm{C}$}

$3.41 \pm 0.13$

$2.40 \pm 0.06$

$3.85 \pm 0.02$

$0.97 \pm 0.02$

$4.93 \pm 0.014$

$0.94 \pm 0.01$

$0.10 \pm 0.002$

$14.63 \pm 0.14$

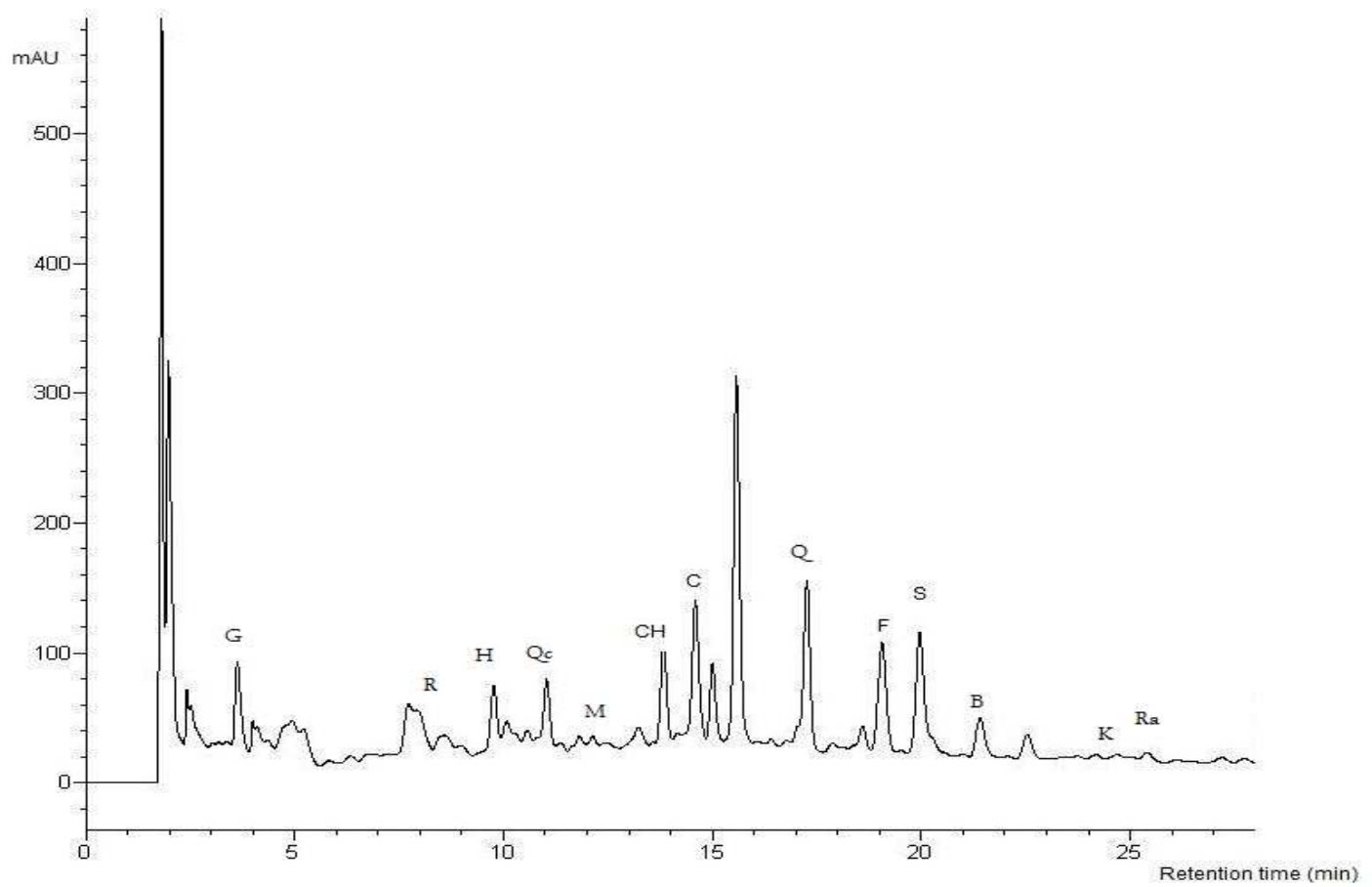

Fig.5. HPLC chromatograms at 254, 325 and $360 \mathrm{~nm}$ for Hypericum perforatum L. extract. G-gallic acid, Rrutin, H-hyperoside, Qc-quercitrin, M-mirecetine, $\mathrm{CH}$-chlorogenic acid, C-caffeic acid, Q-quercetin, F-ferulic acid, S-sinapic acid, B-benzoic acid, K-keampferol, Ra-rhamnetin. 


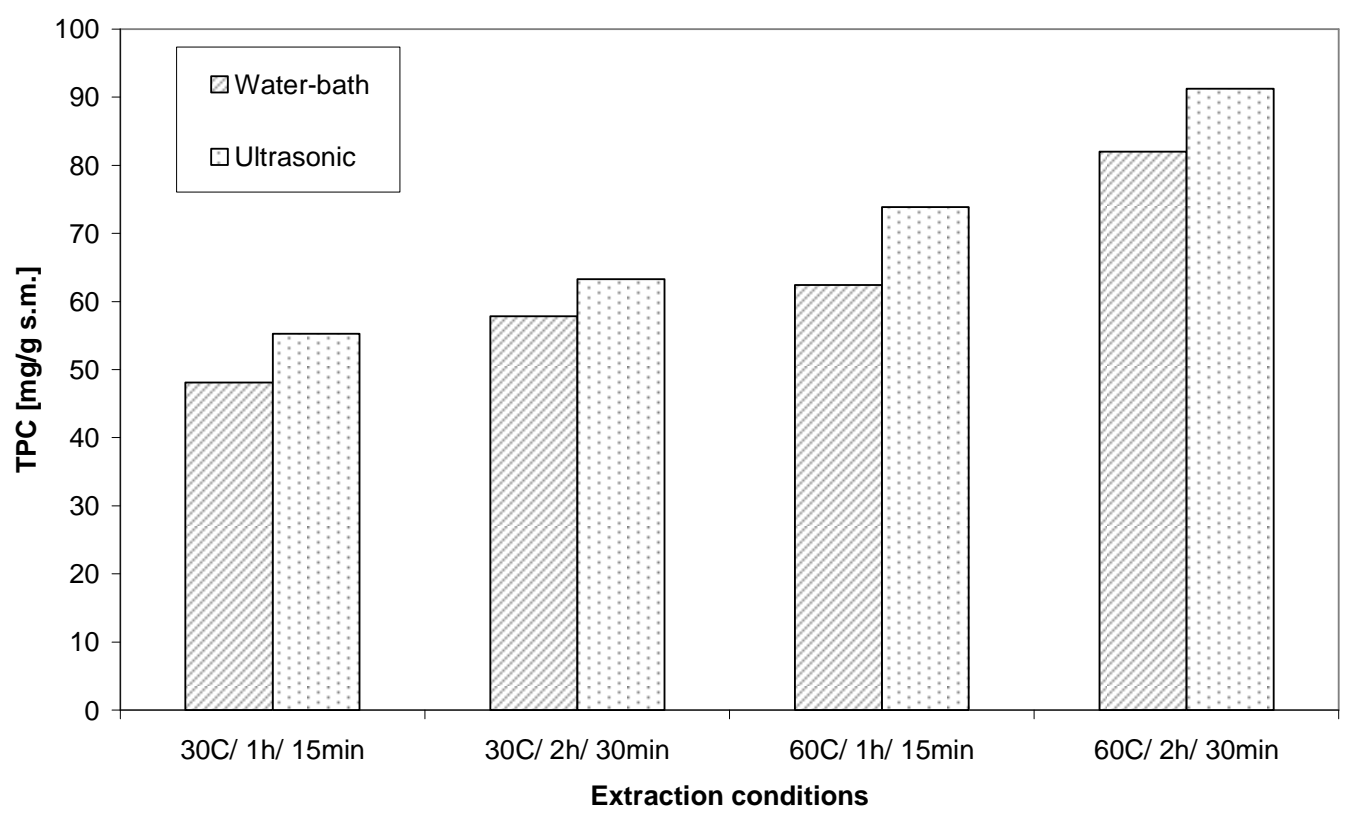

Fig. 6. Impact of various extraction conditions (method, time and temperature) for the total phenolic content in Hypericum perforatum L.

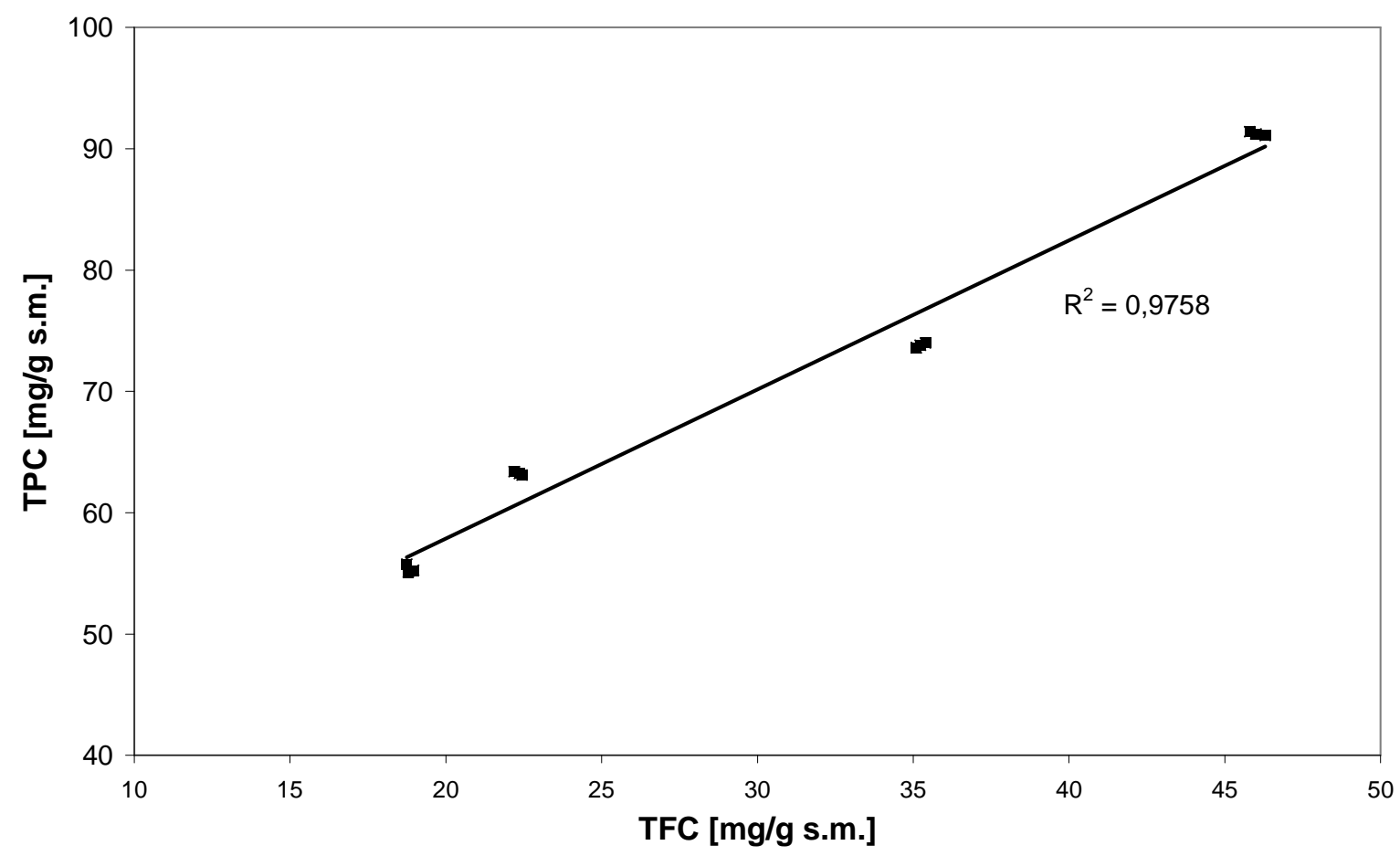

Fig. 7. Correlation between TPC and TFC 


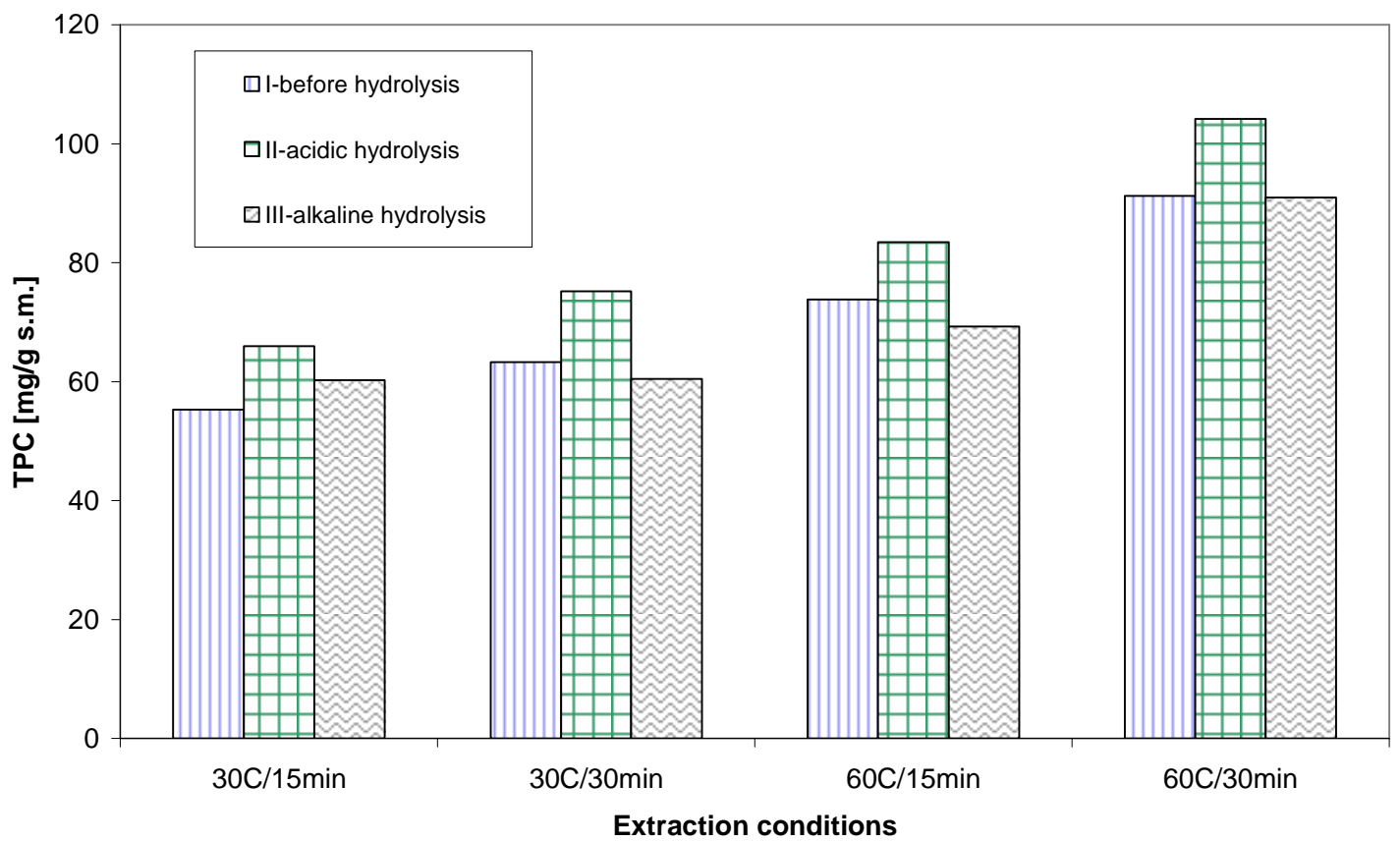

Fig. 8. Impact of different extraction conditions and hydrolysis digestion for the total phenolic content in Hypericum perforatum L.

Table 4.

Comparison of flavonols content - optimization

\begin{tabular}{|c|c|c|c|c|c|c|c|c|c|}
\hline \multirow{3}{*}{$\begin{array}{l}\text { Flavonols } \\
\text { content } \\
\text { [mg/g s.m. } \\
\pm \text { SD)] }\end{array}$} & \multirow{3}{*}{$\begin{array}{c}{[25]} \\
E\end{array}$} & \multicolumn{4}{|c|}{ [26] } & \multirow{3}{*}{$\begin{array}{c}{[27]} \\
E\end{array}$} & \multirow{3}{*}{$\begin{array}{c}{[28]} \\
E(H k w)\end{array}$} & \multirow{2}{*}{\multicolumn{2}{|c|}{ HPLC }} \\
\hline & & \multicolumn{2}{|c|}{ leaves } & \multicolumn{2}{|c|}{ Flowers } & & & & \\
\hline & & $E$ & $H(k w)$ & $E$ & $H(k w)$ & & & $E$ & $H(k w)$ \\
\hline Quercetine & $0.9-2.5$ & $\begin{array}{c}0.31 \\
\pm 0.02\end{array}$ & $\begin{array}{c}6.94 \\
\pm 0.34\end{array}$ & $\begin{array}{c}7.52 \\
\pm 0.36\end{array}$ & $\begin{array}{c}12.4 \\
\pm 0.62\end{array}$ & 12.6 & $0.26-1.54$ & $0.47-5.93$ & $\begin{array}{l}3.98- \\
11.23\end{array}$ \\
\hline Rutin & $\begin{array}{l}6.7- \\
23.1\end{array}$ & $\begin{array}{c}3.45 \\
\pm 0.16\end{array}$ & $\begin{array}{c}0.54 \\
\pm 0.03\end{array}$ & $\begin{array}{c}1.49 \\
\pm 0.06\end{array}$ & $\begin{array}{c}0.61 \\
\pm 0.03\end{array}$ & --- & $\begin{array}{l}6.54- \\
23.30\end{array}$ & $1.56-3.41$ & $0.71-1.10$ \\
\hline Quercitrin & $0.6-2.5$ & $\begin{array}{c}0.38 \\
\pm 0.02\end{array}$ & nd & $\begin{array}{c}1.84 \\
\pm 0.09\end{array}$ & $\begin{array}{c}0.71 \\
\pm 0.03\end{array}$ & 7.8 & $\begin{array}{l}1.33- \\
12.85\end{array}$ & $1.04-3.85$ & $0.57-0.83$ \\
\hline Hyperoside & $\begin{array}{l}3.7- \\
15.8\end{array}$ & $\begin{array}{c}1.78 \\
\pm 0.09\end{array}$ & nd & $\begin{array}{c}4.70 \\
\pm 0.23\end{array}$ & $\begin{array}{c}0.52 \\
\pm 0.02\end{array}$ & ---- & $\begin{array}{l}13.74- \\
41.64\end{array}$ & $1.04-5.49$ & $0.15-0.78$ \\
\hline $\begin{array}{c}\text { TFC } \\
\text { (UV-Vis) }\end{array}$ & --- & $\begin{array}{l}31.70 \\
\pm 0.33\end{array}$ & $\begin{array}{l}44.70 \\
\pm 0.21\end{array}$ & $\begin{array}{l}42.91 \\
\pm 0.25\end{array}$ & $\begin{array}{l}65.25 \\
\pm 0.18\end{array}$ & 54.3 & $\begin{array}{l}208.4- \\
271.1\end{array}$ & $\begin{array}{l}18.97- \\
46.30\end{array}$ & $\begin{array}{c}26.13- \\
61.80\end{array}$ \\
\hline
\end{tabular}

$\mathrm{Nd}$ - not detecetd; E-extraction, $\mathrm{H}(\mathrm{kw})$-acidic hydrolysis, TFC- total flavonoids content 


\section{Conclusion}

In conclusion, water-bath and ultrasonic extraction method with different extraction conditions (temperatures, solvents) and influence of hydrolysis digestion was evaluated. A RP-HPLC-PDA method was developed for quantify simultaneously six phenolic acids and seven flavonols, which are biologically active components in Hypericum Perforatum L. In most cases the highest concentrations of studied phenolic compounds were obtained for ultrasonic extraction by ethanolic solvents at $30 \mathrm{~min}$ and $60^{\circ} \mathrm{C}$. Depending of extraction conditions (extraction method, solvents, time, temperature, acidic or alkaline hydrolysis) we received different amounts of total phenolic compunds, total flavonoids content and studied flavonols determination by HLC-PDA method (the average values were $104.18 \pm 1.14$; $61.80 \pm 0.53 ; 14.63 \pm 0.44 \mathrm{mg} / \mathrm{g}$ respectively). Hydrolyzed digestions have also significantly impact for polyphenol's quantity. Acidic and alkaline hydrolysis, prior to extraction caused the increase the quantitative yield. Total content of studied compunds were compared with total phenolic content (TPC) and total flavonoids content (TFC) determination using spectrophotometric method. In every cases phenolic acids and flavonols constitute only small amount of total polyphenols. while concentration of flavonols was higher than phenolic acids. Because of positive impact of human health and bioavailability of flavonols, flavonoids and phenolic acids in botanical products and natural plant sources, their qualitative and quantitative analysis are necessary and justified.

In this paper, discribing HPLC-PDA method may be applicability to routine analysis and quality control of pharmaceutical products from Hypericum perforatum L., because of its simplicity, easy and fast preparing sample and short analysis time. Because of wide range of exctraction conditions, analysing a lot of botanical samples we may ascertain that obtained results and developed method are reliable and dependable. The proposed method is precision, selective and accuracy.

\section{Literature:}

[1] G. Di Carlo, F. Borrelli, E. Ernst, A.A. Izzo, "St. John's Wort: Prozac from the Plant Kingdom", Trends Pharmacologic Science. (2001) 22 p.292.

[2] J.M. Greeson, B. Sanford, D.A. Monti, “St. John's wort (Hypericum perforatum): a review of the current pharmacological, toxicological, and clinical literature", Psychopharmacology (2001) 153 p.402.

[3] E.C. Tatsis, S. Boeren, V. Exarchou, A.N. Troganis, J. Vervoort, I.P. Gerothanassis, "Identification of the major constituents of Hypericum perforatum by LC/SPE/NMR and/or LC/MS", Phytochemistry (2007) 68 p.383.

[4] P. Avato, F. Raffo, G. Guglielmi, C. Vitali, A. Rosato, "Extracts from St John's wort and their antimicrobial activity", Phytother Res (2004) 18:230-232 [5] V. Butterweck, G. Jurgemlienk, A. Nahrstedt, H. Winterhorff, "Flavonoids from Hypericum perforatum Show Antidepressant Activity in the Forced Swimming Test", Planta Med. 66 (2000) 3.

[6] RBH. Wills, K. Bone, M. Morgan, "Herbal products: active constituents, mode of action and quality control", Nutr Res Rev (2000) 13:47-77

[7] BA. Silva, F. Ferreres, JO. Malva, ACP. Dias, "Phytochemical and antioxidant characterization of Hypericum perforatum alcoholic extracts", Food Chem (2005) 90:157-167

[8] V. Exarchou, YC. Fiamegos, TA. van Beek, C. Nanos, J. Vervoot, "Hyphenated chromatographic techniques for the rapid screening and identification of antioxidants in methanolic extracts of pharmaceutically used plants," J Chromatogr A (2006) 1112:293-302

[9] M. Urba'nek, L. Blechtova', M. Pospis`ilova', M. Pola's`ek, "On-line coupling of capillary isotachophoresis and capillary zone electrophoresis for the determination of flavonoids in methanolic extracts of Hypericum perforatum leaves or flowers", J Chromatogr A (2002) 958:261-271

[10] P. Avato, G. Guglielmi, "Determination of major constituents in St. John's Wort under different extraction condition", Pharm Biol (2004) 42:83-89

[11] T. Walle, AM. Browning, LL. Steed, SG. Reed UK. Walle, "Flavonoid glucosides are hydrolyzed and thus activated on the oral cavity in humans", J Nutr (2005) 135:48-52

[12] K. Lombard, E. Peffley. E. Geoffriau, L. Thompson, A. Herring, "Quercetin in onion (Allium cepa L.) after heat-treatment simulating home preparation", J Food Comp Anal (2005) 18:571-581

[13] J.S. Zhang, X.L.Wang, Q. Luo, Chinese Trad. Pat. Med. 28 (2006) 709. 
[14] X.L.Wang, J.S. Zhang, Q. Luo, Chinese Trad. Med. 29 (2006) 1047.

[15] L. Yu, J.M. Li, Y.R. Li, Appl. Chem. Ind. 35 (2006) 755.

[16] AH. Draves, SE. Walker, "Determination of hypericin and pseudo- hypericin in pharmaceutical preparations by liquid chromatography with fluorescence detection"J Chromatogr A (2000) 749:57-66

[17] A. Berthod, "Practical approach to high-speed counter-current chromatography", J. Chromatogr. 550 (1991) 677.

[18] Y.Wei, et.al., "Application of analytical and preparative high-speed counter-current chromatography for separation of lycopene from crude extract of tomato paste", J. Chromatogr. A 929 (2001) 169.

[19] S. Yao, J.G. Luo, X.F. Huang, "Application of preparative high-speed counter-current chromatography/preparative high-performance liquid chromatography mode in rapid separation of saponins", J. Chromatogr. B 864 (2008) 69.

[20] X.L. Cao, et.al., "Separation of Aloins A and B from Aloe Vera Exudates by High Speed Countercurrent Chromatography" J. Liq. Chromatogr. Rel. Technol. 30 (2007) 1657.

[21] H.M. Merken, G.R. Beecher, in: C.T. Ho (Ed.), Quality Management of Nutraceuticals

(ACS Symposium Series,No. 803), American Chemical Society,Washington, DC, 2002, p. 21.

[22] Y. Shan, A.S. Morgenstern, "Analysis of the isolation of a target component using multicomponent isocratic preparative elution chromatography", J. Chromatogr. A 1041 (2004) 53.

[23] St. Kohlmunzer, Farmakognozja, Wydawnictwo Lekarskie PZWL, Warszawa 2007.

[24] British Pharmacopoeia, 2005

[25] Frances F. Liu et al. „Evaluation of major active components in St. John's Wort by HPLC-DAD and HPLC - (ESI) MS", Journal of Chromatography A, 888 (2000) 85-92.

[26] M. Biesaga et al., "Extraction and Hydrolysis Parameters for Determination of Quercetin in Hypericum perforatum" Chromatographia (2007), 65, 701-706.

[27] YunWei et al., "Separation of epigallocatechin and flavonoids from Hypericum perforatum L. by high-speed counter-current chromatography and preparative highperformance liquid chromatography" Journal of Chromatography A, 1216 (2009) 4313-4318

[28] Vijeshwar Verma et. al., "Phenolic constituents and genetic profile of Hypericum perforatum L. from India", Biochemical Systematics and Ecology 36 (2008) 201206 